\title{
Improving Student Well-being in School
}

\section{Farah Aulia}

Universitas Negeri Padang, Padang, Indonesia,凹bundarafa1801@gmail.com

\begin{abstract}
Schools have an important role in supporting student well-being as microsystems that affect student development, social contexts where students interact and influence each other with teachers, peers and staff as well as schools as a community. Student well-being is related to a number of important factors including academic achievement, physical and mental health, satisfying interpersonal relations and success at work. This article examines the role of schools in efforts to improve student well-being.A whole-school approach that involves all the components in a school is needed to support student well-being.
\end{abstract}

Keywords:Student well-being, school,whole-school approach

This is an open access article distributed under the Creative Commons 4.0 Attribution License, which permits unrestricted use, distribution, and reproduction in any medium, provided the original work is properly cited. $\mathcal{O} 2018$ by author and Faculty of education, UniversitasNegeri Padang.

\section{Introduction}

Well-being has a very important role in learning and life outcomes of children and adolescents. Some research shows that well-being is related to important factors in the lives of children and adolescents such as academic achievement (Ainley, 1991; Bourke \& Smith, 1989, in Ching Mok \& Flynn, 2002), success in work, positive physical and mental health and satisfaction in interpersonal relationships (Lyubomirsky, King and Diener, 2005). Children who have a high level of well-being will be more cooperative, confident, creative, tolerant and altruistic (Cohen \& Pressman, 2006; Lyubomirsky et al., 2005). Student achievement in school is also an additional effect on student well-being. Students who have high achievement feel better at school than students with low achievement (Hascher, 2011). Student well-being at school is considered a leading indicator of the mental health of school-based students (Long, Huebner, Weddel \& Hills, 2012; Vedder, Boekaerts, Seeger,2005). As a supporting factor, high well-being will enable children to be positively involved and confident with their environment and provide full benefits for opportunities to learn (MashfordScott, Church \& Collette, 2012).

Student well-being is also an important indicator that reflects the development of students in school (Huebner, 2010;Gilman\& Huebner, 2003; Liu, Tian, Huebner, Zheng, Li 2015; Tian, Du \& Huebner, 2014). The cognitive component of student well-being in school, namely school satisfaction, has a connection with a number of aspects of student functioning in school and its development in general (Verkuyten \& Thijs, 2002), such as attachment to school, academic competence perceived by students, and physical and mental health in general (Suldo et al., 2014). Children who report that they 
are very happy show positive functioning in intrapersonal, interpersonal, and school-related domains (Gilman \& Huebner, 2006; Suldo \& Huebner, 2006).

Contrarily, children who feel very unhappy with their lives show diffuse difficulties including problems with aggressive behavior, internalization of behavior, suicidal thoughts, risky sex decision makers, drug and alcohol use, eating problems and physical health and physical inactivity. They are also vulnerable to victimization of victimization both physically and relationally (Huebner, Gilman \& Suldo, 2006). A number of studies also show that poor mental health, one of which is shown by low well-being at an early age, will last throughout one's life (Carter et al, 2004; Caselman and Self, 2008; Davis et, al 2010a).

Unlike the case with research on adult wellbeing that has developed rapidly over the past decade, research on children's well-being, especially in the school context is still scarce. In Indonesia alone there is also no specific policy that emphasizes the importance of student well-being in schools. In Undang-Undang No. 4 of 1979 concerning child well-being, Article 1 states that child well-being is a system of life and livelihood of children that can ensure the growth and development of children naturally both spiritually, physically and socially. Explicitly, the Act has not explained about indicators of growth and development that are reasonable in children and more specifically the wellbeing in schools as part of educational goals.

\section{Definition of Well-being}

There is no one agreement from experts about the definition of well-being. But in general well-being can be explained as a multidimensional construct. According to the World Health Organization (WHO) well-being is explained in the definition of positive mental health, namely defined as a state of well-being in which each individual has his or her own potential, can cope with the normal stresses of life, can work productively and fruitfully, and is able to make a contribution to her or his community. In positive psychology, there are two perspectives that examine well-being, namely hedonistic and eudaimonic. The hedonistic perspective emphasizes that well-being associated with subjective happiness and that attention to pleasant experiences versus unpleasant experiences is widely interpreted to include all judgments about the good / bad elements of life (Ryan \& Deci, 2001). In this hedonic model, well-being consists of three parts: life satisfaction, the presence of positive emotions and the absence / lack of negative emotions (Diener, Emmons, Larsen \& Griffin, 1985). On the other hand, the eudaimonic perspective explains well-being, that psychological health will be achieved when a person fulfills his potential, functions at an optimal level and or realizes his own potential (Lent, 2004). This difference in perspective also raises differences in defining student wellbeing in the school context.

Specific for student well-being, Long et al .(2012) describes the well-being of students in schools that are defined using the well-being theory of Diener et al. (1999) which consists of (a) positive affect, namely positive emotions that often appear like happy and interested; b) negative affect that is rarely the appearance of angry and anxious emotions and c) cognitive assessment of general quality of life (eg school experience). According to Engels et al. (2004), student well-being in school is defined as the expression of the life of positive emotions which is the result of harmony of a number of specific environmental factors on the one hand and the expectations of each student on the other. Hofman, Hofman \& Guldemond (1999) as students' attitudes toward school. This attitude can be divided into four aspects, namely: a) general attitudes related to school life, b) attitudes related to teachers, c) attitudes related to peers and d) attitudes related to school and building organizations. Samdal, Wold 
and Bronis (1999) then add this aspect of student attitudes to the degree to which students feel safe and comfortable in school (meaning that they don't feel lonely and bullied) and the degree to which students feel safe in school as an indicator of school well-being.We can conclude that student wellbeing is related to positive students' emotions that are dominant during school, lack of negative emotions and how they can undergo their function as students in school.

\section{School asImportant Context for Supporting Student Well-being}

Bronfenbrenner (1994) describes environmental influences as a context for child development. Through this Ecological Theory, Bronfenbrenner emphasizes the importance of studying about children in the context of multiple environments in order to understand their development more comprehensively. At the closest level to the child is microsystem, namely the individual experience in settings that are directly related to them. Microsystems include the family environment and the school environment. Families and schools are autonomous children's microsystems, but both will interact with each other affecting children's development. It is important to make children feel a pleasant experience at school while learning the various cognitive abilities needed. Research shows that feelings of pleasure or positive emotions are indicators of wellbeing, and also become the basis for the formation of well-being in the future. Conversely negative emotions will make the ability to think and behavior become inhibited and reduce the source of learning and adaptation (Fredrickson, 2001). As explained by Masten \& Coatsworth (1998) the context in which individuals grow and develop has an influence role in supporting their adaptation and adjustment.

Children spend quite a lot of time in school, from elementary school to high school. On average a day in Indonesian children spend around 5-8 hours a day in school interacting with peers, teachers and staff. Schools can play a role on both sides of the child, namely the context that can support their well-being or vice versa can have a negative impact on their well-being. On the supporting side, schools not only act as important contexts for learning various life skills, but also play a role in identity formation, interpersonal relationships and other skills (Greenberg et al., 2003). Contrarily, pressure on school assignments, and various negative events can be experienced by students in schools which actually reduce their subjective well-being. As explained by Aulia (2016) that there are $38.9 \%$ of elementary school students in Yogyakarta experiencing bullying by peers in school. Riset Kesehatan Dasar conducted bay Health Ministry in 2013 also reported that the prevalence of mental emotional disorders in the age group of 15 years and older and still in school was $6.0 \%$ or equal to the prevalence of national emotional mental disorders (Dinkes, 2013).

In addition, the school is also a formal organization that has structure and administration. This has become a hallmark of schools in an effort to support mental health. Payne, Gottfredson \& Gottfredson (2003) describe school as a community where members know each other, care for each other, and support one another, have a common goal and a feeling of sharing, and with that they will actively contribute and feel personally bound. In relation to mental health intervention efforts, schools are social contexts that are more accessible than family or community contexts (Wyn et al., 2000). Students who need psychological intervention are more easily accessible because they are in one setting, namely school.

Determinants of student well-being 
Student well-being can be influenced by a number of factors including gender (John-Akinola \& Nic-Ghabain, 2014; Liu et al., 2015), self-esteem (Baumeister et al. 2003;; Danielsen et al., 2009; Tian et al. 2013), gratitude (Tian et al., 2013), teacher-student relations (Durlak \& Wells, 1997; MurrayHarvey, 2010; Sarkova, Bacikova-Sleskova, Geckova, van den Hevel \& van Dijk, 2014 ), social support from teachers (Baker, 1999; Danielsen, Samdal, Hetland \& Wold, 2009; DeSantis-King, Huebner, Suldo \& Valos, 2006; Ito \& Smith; 2006; Liu, Tian, Huebner \& Zheng , 2015; Rosenfeld, Richman \& Bowen, 2000; Suldo \& Huebner, 2008), peer relationships (John-Akinola \& Nic-Ghabain, 2014;Engels, Aelterman, Van Petegem \& Schepe , 2004; Konu, Lintonen \& Rimpela, 2002; Liu et al., 2015; Lohre, Lydersen \& Vatten, 2010; Shen Cu Po, Saucier, Hafner, 2010; Reddy, Rhodes \& Mullhal, 2003 \& Liu, May, Tian \& Huebner, 2016,) school climate (John-Akinola \& Nic-Ghabain, 2014; Engels et al .. 2004; Liu et al. 2015; Opdenakker, 2000; Verkuyten \& Thijs, 2002;), and school conditions (Konu et al., 2002).

In a more integrative and comprehensive form, Konu, Litonen\& Rimpela (2003) explained that there are three domains that compose a model of school well-being, namely a) Having, explained by the conditions of the school which include the physical condition of the school, organization and school structure, b) Loving, explained as social relations which include the school climate, teacherstudent relations, bullying, relationships with peers and group dynamics, and c) Being, described as means for self fulfillment relating to self esteem, the influence of school decision making on students. Finally, this model adds health conditions related to illness or symptoms of health problems experienced by students. This model from Konu \& Rimpela (2003) provides an illustration that student well-being is related to the overall system of domains in schools.

Furthermore, Van Petegem et al. (2007) explained the role of student characteristics, teacher characteristics and school characteristics as determinants of student well-being in school. There are three levels that can affect the well-being of students directly or indirectly. At the individual student level, students' perceptions of teacher's interpersonal behavior and student characteristics themselves become factors that directly affect student well-being. At the class/classroom teacher level, teacher perceptions of interpersonal behavior, teacher well-being and class characteristics are factors that influence student well-being. Finally, at the school level, the characteristics of schools are factors that also affect student well-being.

The model proposed by Konu, Litonen \& Rimpela (2003) and Van Petegem et al (2007) shows that to be able to support the welfare of students in schools requires the involvement of all components in the school starting from students, parents, teachers, principals, staff, and support community.

Whole-School Approach to Improve Student Well-being in School

When viewed from the determinants of student well-being, there are a number of factors that contribute to the well-being of students in schools, including peers, teachers, school climate, curriculum, family/community and general school conditions. Overall, all of these factors need to be involved in order to support student well-being in schools (whole-school approach). In a wholeschool approach, involving all members of the school community, start from school staff, parents, students and the wider community to build a positive culture where everyone has a sense of belonging. Therefore, schools also have a goal to be able to meet the needs of the school community, which involves how teachers create a positive social and emotional environment in learning, ensure that learning takes place interactively, build collaboration with families and other supporting 
communities more broadly. This approach is not only related to systems and structures within the school, but also to the local community and a wider mental health system that can help provide services that are relevant to school needs.

World Health Organization in 1997 has launched the Health Promoting School Program (HPS) a holistic approach in promoting health in schools. This program is quite popular and has been adopted by a number of countries in the world. In the review and meta-analysis literature conducted by Langford et al. (2015) shows that this program has quite good effectiveness in mental health interventions and wellbeing, although the results vary. The framework used in this HPS includes school curriculum, environment and school settings and involves families and communities in an effort to promote mental health and wellbeing of students.

Tabel 1. The Health Promoting School Framework

\begin{tabular}{ll}
\hline School curriculum & $\begin{array}{l}\text { Health education topics are promoted through } \\
\text { the formal school curriculum }\end{array}$ \\
\hline Ethos and/or environment & $\begin{array}{l}\text { Health and well-being of student are promoted } \\
\text { through hidden or informal curriculum, which } \\
\text { encompasses the values and attitudes promoted } \\
\text { within the school and the physical environment } \\
\text { and setting of the school }\end{array}$ \\
\hline Families and/or communities & $\begin{array}{l}\text { School seek to engage with families, outside } \\
\text { agencies and the wider community in } \\
\text { recognition of the importance of these other } \\
\text { spheres of influence on children's health }\end{array}$ \\
\hline
\end{tabular}

(Adapted from : Langford et al, 2015)

One of the countries that have adopted HPS is Australia with the MindMatters program designed to provide a framework that integrates mental health education with interventions for promotion. The program provides a comprehensive first approach to the promotion of mental health of Australian adolescents through school programs (Wynn et al, 2000). This program was later adapted in Germany by Franze \& Paulus (2009) which shows the results that teachers feel more positive about schools and feeling under less pressure. There are some positive changes within the spectrum of mental health in MindMatters schools. Students are improved in terms of social competence. Lee, Cheng, Fung \& Leger (2006) found that there was an increase in student life satisfaction in the HPS program conducted at schools in Hong Kong.

Health Promoting School can be just one of the programs that can be done to support the wellbeing of students in school, because cultural, values and policy differences will have an effect. Nevertheless, the important emphasis is to be able to help students improve their well-being in school, it cannot be done by only one party, but involves the entire stake holder in the school as a community that wants to achieve a common goal.

\section{Conclusion}

Schools have an important role in supporting mental health and student well-being. Students who are well-being will have a positive impact on the learning process, one of which is in academic achievement. Therefore, it is important for policy makers to make student well-being a part of 
educational goals other than academic achievement. A good school is a school that promotes student well-being, as well as academic achievement. Equip teachers and staff with knowledge and skills that can support their capacity to support student well-being. Building school collaboration with the parent community and other support communities is also part of supporting students' well-being in school.

\section{References}

Ainley, J., Foreman, J., \&Sheret, M. (1991). High school factors that influence students to remain in school. Journal of Education Research, 85 (2), 69-80. doi: 10.1080/00220671.1991.10702816

Aulia, F. (2016). Children experience in school life \& its association with well-being. Proceeding International Conference oh Health \& Well-being (ICWHB).

Bronfenbrenner, U. (1994). Ecological Models of Human Development. International Encyclopedia of Educations, 3, 1643-1647.

Carter, A.S., Briggs-Gowan, M. J., \& Ornstein D. N. (2004). Assessment of young children's social emotional development and psychopathology : recent advances and recommendation for practice. Journal of Child Psychology and Psychiatry, 45(1), 109-134. doi:10.1046/j.00219630.2003.00316.x

Caselman, T.D., \& Self, P.A. (2008). Assessment instruments for measuring young children's social emotional behavioral development. Children \& School, 30 (2), 103-115. doi :10.1093/cs/30.2.103

ChingMok, Magdalena Mo., Flynn, Marcellin. 2002. Determinant of students's quality of school life : A path model. Learning Environment Research, Vol. 5, 275-300. Belanda : Kluwer Academic Publishing.

Cohen, S., \& Pressman, S.D. (2006). Positive affect and health. Current Directions in Psychological Science, 15(3), 122-125. doi : 10.1111/j.0963-7214.2006.00420.x

DeSantis-King, A.L., Huebner, S.,Suldo, S.M \& Valois, R.F. (2006). An ecological view of school satisfaction in adolescent : Linkage between social support and behavior problem. Applied Research in Quality of Life, 1, 279-295. doi :10.1007/511482-007-0921-7.

Diener, E., Suh, E. M., Lucas, R. E., \& Smith, H. L. (1999). Subjective well-being: Three decades of progress. Psychological Bulletin, 125, 276-302.

Durlak, J.A \& Wells, A.M. (1997). Primary prevention mental health programs for children and adolescent : A meta-analytic review. American Journal of Community Psychology, 25(2), 115-152. doi :10.1023/a:1024654026646

Engels, N., Aelterman, A.., Van Petegem, K., \&Schepens, A.(2004). Factors which influence the well being of pupils in Flemish secondary schools. Educational Studies, 30(2). doi : $10.1080 / 0305569032000159787$. 
Franze, M., Paulus, P. (2009). MindMatters- a programme for the promotion on mental health in primary and scondary schools. Results of an evaluation on German language adaptation. Health Education, 109 (4), 369-379.

Fredricks, J.A., Blumenfeld, P.C., \& Paris, A.H. (2004). School engagement : potential of concept, state of evidence. Review of Educational Research, 74, 59-109. doi :10.3102/0034654307400105

Gilman,R., \& Huebner, E.S. (2003). A review of life satisfaction research with children and adolescent. School Psychology Quarterly, 18(2), 192-205. doi:10.1521/scpq.18.2.192.21858

Gilman, R \& Huebner, E.S. (2006). Characteristic of adolescent who report very high life satisfaction. Journal of Youth \&Adolesence, ,35, 311-319. doi :10.1007/s10964-006-9036-7

Greenberg, M.T., Weissberg, R.P., O’Brien, M.U., Zins, J.E., Frederick, L., Resnik, H., Elias, M.J. (2003). Enhancing school-based prevention and youth development through coordinated social, emotional and academic learning. American Psychologist, 58,6/7, 466-474. doi : 10.1037/0003066X.58.6-7.466

Hascher, T. (2011). Well-being. In S. Jarvela (Ed.).,Social and Emotional Aspect of Learning, pp. 99105,.Oxford: Elsevier.

Hofman, R. H., Hofman, W.H.A., \&Guldemon, H. (1999). Social and cognitive outcomes : A comparison of contexts of learning. School Effectiveness and School Improvement, 10, 352-366.doi: 10.1076/sesi.10.3.352.3499

Huebner, E.S., Suldo, S.M., Smith, L.C., \& McKnight, C.G. (2004). Life satisfaction in children and youth : Empirical foundations and implication for school psychologist. Psychology in The School, 41(1), 81-93. doi: 10.1002/pits.10140

Ito, A \& Smith, D.C. (2006). Predictor of school satisfaction among Japanese and US youth. The Community of Psychologist, 38, 19-25. doi : 10.1037/e628622012-468

John-Akinola, Y.O.,\&Nic-Gabhainn, S. 2014. Children's participation in school: a cross-sectional study of the relationship between school environments, participation and health and well-being outcomes. BMC Public Health,14(1),964. doi : 10.1186/1471-2458-14-964.

Konu. A., Alanen, E., Lintonen, T., \&Rimpela., M. (2002). Factor structure of the school wellbeng model. Health Education Research : Theory \& Practice, 17(6), 732-742. doi :10.1093/her/17.6.732

Langford, R., Bonell, C., Jones, H., Pouliou, T., ...........Campbell, R. (2015). The world health organizations health promotion school framework : A cochrane systemic review \& metaanalysis. BMC Public Health, 15, 130.

Lee, A., Cheng, F.F.K., Fung, Y., Leger, L.S. (2006). Can health promoting school contribute to the better health \& wellbeing of young people? The Hongkong experience. Journal of Epidemiologi Community, 60(6), 530-536. 
Lent, R.W. (2004). Toward a unifying theoritical and practical perspective on wellbeing and psychological adjustment. Journal of Counseling Psychology, 51(4), 482-509. doi : 10.1037/00220167.51.4.482

Liu, D \& Zhang, R. (2006). A preliminary research on middle school student's academic well-being and its major influential factors. Frontiers Educational China, 2, 316-327.doi : 10.1007/s11516-00600107

Liu, W., Mei, J., Tian, L., \& Huebner, E.S. (2016). Age and gender differences in the relation between school-related social support and well-being in school among students. Social Indicator Research.doi: 10.1007/s11205-015-0873-1

Liu,W.,Tian, L., Huebner, E.S., Zheng, X., \& Li., Z. (2015). Preliminary development of the elementary school student's subjective well-being in school scale. Social Indicator Research,120, 917-937. doi :10.1007/s11205-014-0614-x

Lohre ,A., Moksnes ,U. K., \&Lillefjell, M. (2013). Gender differences in predictors of well-being in school? Health Education Journal, 73 (1), 90-100. doi : 10.1177/0017896912470822

Long, R, F., Huebner, E. S, Wedell, D. H., \& Hills K,J (2012). Measuring school related well-being in adolescent. American Journal of Orthopsychiatry, 82 (1), 50-60. doi : 10.1111/j.19390025.2011.01130.x

Lyubomirsky, S., King, L., Diener, E. (2005). The Benefits of Frequent Positive Affect: Does Happiness Lead to Success?.Psychological Bulletin 2005, 131(6), 803- 855. the American Psychological Association. doi : 10.1037/033-2909.131.6.803

Mashford-Scott, A., Church, A.,\& Tayler, C. (2012). Seeking children's perspective on their well-being in early childhood settings. IJEC, 11: 231-247.doi : 101007/s13158-012-0069-7

Masten, A.S \&Coatsworth, J.D. (1998). The development of competence in favorable and unfavorable environment . American Psychologist, 53(2), 205-220. doi : 10.1037//0003-066x.53.2.205.

Murray-Harvey, R. (2010). Relationship influences on student's academic achievement, psychological health and well-being at school. Educational \& Child Pscyhology, 27(1). Retrieved from : http://www.wellbeingaustralia.com.au/wba/pdfs/ecp27_1/ECP27_1\%20Murray-Harvey.pdf

Payne, A.A., Gottfredson, D.C., Gottfredson, G.D. 2003. Schools as communities : The relationship among communal school organization, student bonding and school disorders. Criminology, Vol. $41, N o .3$

Reddy, R., Rhodes, J., Mullhal, P. (2003). The influence of teacher support on student adjustment in the middle school years : a latent growth curve study. Development and Psychopathology,15,119138. doi : $10.1017 / \mathrm{s} 095457940300075$

RisetKesehatanDasar. (2013). DepartemenKesehatan RI 
Rosenfeld, L.B., Richman, J.M., Bowen, G. L. (2000). Social support networks and school outcomes : the centralities of the teacher. Child \& Adolescent Social Work Journal, 17 (3),205-226. doi:10.1023/a:1007535930286

Ryan, R.M \&Deci, E.L. (2017). Self Determination Theory : Basic Psychological Needs in Motivation, Development and Wellness. New York : Guilford Press.

Samdal, O., Wold, B., Bronis, M. (1999). Relationship between studen

t's perception of school environment, their satisfaction with school and perceived academic achievement : An International study. School Effectiveness and School Improvement,10, 296-320. doi : 10.1076/sesi.10.3.296.3502

Sarkova, M., Bacikova-Sleskova, M., Geckova, A.M., Wim van den Hevel, Z.K., vaDijk, J.P. (2014). Adolescent's psychological well-being and self esteem in the context of relations at school. Educational Research, 56(4), 367-378. doi : 10.1080/00131881.2014.965556

Suldo, S.M., Frank, M.J., Chappel, A.M., Albers., M.M., Bateman, L.P. (2014). American high school student's perception of determinants of life satisfaction. Social Indicator Research, 118(2), 485514. doi:10.1007/s11205-013-0436-2

Tian, L., Du, M., Huebner, E.S. (2014). Effects of gratitude on Elementary schools student's subjective well-being in schools : The mediating role of prosocial behavior. Social Indicator Research, 122(3), 887-904. doi :10.1007/s11205-014-0712-9.

Tian, L., Liu, B., Huang, S., Huebner, E.S.(2012). Perceived social suport and school well-being among Chinese early and middle adolescent : The meditational role of self esteem. Social Indicator Research,113(3), 991-1008. doi : 10.1007/s11205-012-0123-8

Tian, L., Wang, D., \& Huebner, E.S. (2014). Development and validation of the Brief Adolescent's Subjective Well-Being in School Scale (BASWBSS). Social Indicator Research, 120(2), 615-634.doi : 10.1007/s11205-014-0603-0.

Van Petegem, K.,Aelterman,A.,VanKeer, VH., Rosseel, Y. (2008). The influence of student characteristics and interpersonal teacher behaviour in the classroom on student's wellbeing. Social Indicator Research, 85,279-291. doi 10.1007/s11205-007-9093-7

Vedder, P., Boekaerts, M., Seegers, G. (2005). Perceived social support and school well-being ; the role of students ethnicity. Journal of Youth and Adolescence, 34(3), 269-278. doi: 10.1007/s10964-005$4313-4$

Verkuyten, M \&Thijs, J. (2002). School satisfaction of elementary school children : The role of performance, peer relation, ethnicity and gender. Social Indicators Research, 59(2) : 203-228. doi:10.1023/a:1016279602893

Wyn, J., Cahill. H., Holdsworth, R., Rowling, L., carson, S. (2000). Mindmatters, a whole-school approach promoting mental health \& well-being. Australian \& New Zealand Journal of Psychiatry, $34,594-601$ 